\title{
Oral contraceptive use and prevalence of infection with Chlamydia trachomatis in women
}

\author{
G R KINGHORN AND M A WAUGH \\ From the Department of Genitourinary Medicine, Leeds General Infirmary, Leeds
}

SUMMARY One thousand and eighty non-pregnant women aged 16-34 years, presenting for the first time at a clinic for sexually transmitted diseases (STD), were examined and screened for infection with Chlamydia trachomatis, Neisseria gonorrhoeae, Trichomonas vaginalis, and Candida species. The respective prevalence rates were $21 \cdot 1 \%, 20 \cdot 7 \%, 13 \cdot 4 \%$, and $27 \cdot 8 \%$. Isolation rates for $C$ trachomatis, either occurring alone or in association with other genital infections, were significantly greater in women using oral contraceptive agents. This was not because oral contraceptive users were more promiscuous.

The findings strengthen the case for providing a routine chlamydial culture service for women attending STD clinics. They also indicate that the likelihood of chlamydial infection in women taking oral contraceptives is increased.

\section{Introduction}

Infection with Chlamydia trachomatis is now recognised as a major cause of genital tract infection. In contrast to infections in men, who usually present with nongonococcal urethritis, those in women often have no specific symptoms or signs. ${ }^{1}$ Unless routine cultures for this organism are undertaken, such infection is easily overlooked. Several recent studies have suggested that chlamydial infection is promoted by the use of oral contraceptive agents, ${ }^{2-4}$ although this is disputed by others. ${ }^{5-9}$ If such an effect does exist, it is not clear whether this is secondary to differences in the sexual behaviour of oral contraceptive users and non-users leading to increased exposure to $C$ trachomatis or due to a specific hormonal effect causing increased susceptibility to the organism.

Since 1975 women with new complaints attending the department of genitourinary medicine at Leeds General Infirmary have had specimens taken routinely for the culture of $C$ trachomatis at their first attendance. The aims of the present study were: (1) to compare the isolation rate for $C$ trachomatis with that for other major genital pathogens and to compare the rate in 1979 with that found in a previous study ${ }^{10}$; and (2) to examine more closely the possible association between chlamydial infection and the use of oral contraceptive agents.

Address for reprints: Dr $G \quad R$ Kinghorn, Department of Genitourinary Medicine, Special Clinic, Royal Infirmary, Sheffield S6 3DA

Accepted for publication 17 November 1980

\section{Patients and methods}

The study population consisted of 1080 consecutive non-pregnant women aged between 16 and 34 years presenting for the first time to the department of genitourinary medicine, Leeds General Infirmary, Leeds, between 1 January and 30 September 1979.

\section{SPECIMEN COLLECTION}

After a full history had been taken, patients were examined in the lithotomy position. Specimens for immediate microscopy and the appropriate culture were taken from the urethra and cervix for the identification of $N$ gonorrhoeae and from the posterior forniceal pool for $T$ vaginalis and Candida species. The methods of specimen collection, cultural techniques, and diagnostic criteria have been described. ${ }^{11}$

Specimens for culture for $C$ trachomatis were collected by rotating a cottonwool swab in the cervical canal and on any exposed ectopic columnar epithelium. The swabs were then placed in transport medium (McCoy cell growth medium with $0 \cdot 5 \%$ glucose and $10 \%$ sorbitol) and stored at $4^{\circ} \mathrm{C}$ before being transferred to the virology laboratory. The method used for isolating $C$ trachomatis in untreated McCoy cells has been described. ${ }^{12}$

\section{DATA ANALYSIS}

For analysis of the results patients were divided into two groups, those who used oral contraceptives and those who used other methods or no contraception at all. Demographic and clinical data on the two groups 
infected with $C$ trachomatis were compared. In this study the presence of cervicitis was defined as the presence of mucopurulent or purulent cervical secretion showing $>5$ white cells per high-power field ( $\times 100$ magnification) associated with one or more of the following: hyperaemia of the ectocervix, hypertrophic ectopy of the columnar epithelium, and contact bleeding from the endocervical canal. Statistical analysis was made by the $\chi^{2}$ test with Yates's correction.

\section{Results}

\section{ISOLATION RATES}

The isolation rates for $C$ trachomatis, $N$ gonorrhoeae, $T$ vaginalis, and Candida species in the 1080 women studied are given in table I. $C$ trachomatis was found in $160(26.6 \%)$ of all 601 oral contraceptive users compared with only $72(15 \%)$ of all 479 non-users $(\mathrm{P}<0.001)$. $T$ vaginalis was found significantly less frequently in oral contraceptive users $(11 \%)$ than in non-users $(16.5 \%)(\mathrm{P}<0.02)$. There were no significant differences between oral contraceptive users and non-users in the incidences of $N$ gonorrhoeae, Candida species, or of women uninfected with any of these four pathogens.

TABLE I Isolation rates in relation to use of oral contraceptives

\begin{tabular}{|c|c|c|c|c|c|c|}
\hline \multirow[b]{3}{*}{ Pathogens } & & & \multicolumn{4}{|c|}{ Oral contraception } \\
\hline & \multicolumn{2}{|c|}{ All women } & \multicolumn{2}{|c|}{ Users } & \multicolumn{2}{|c|}{ Non-users } \\
\hline & No & $\%$ & No & $\%$ & No & $\%$ \\
\hline $\begin{array}{l}\text { Chlamydia trachomatis } \\
\text { Neisseria gonorrhoeae } \\
\text { Trichomonas vaginalis } \\
\text { Candida species } \\
\text { No pathogen isolated } \\
\text { Total No of patients }\end{array}$ & $\begin{array}{r}232 \\
224 \\
145 \\
300 \\
360 \\
1080\end{array}$ & $\begin{array}{l}21 \cdot 5 \\
20 \cdot 7 \\
13 \cdot 4 \\
27 \cdot 8 \\
33 \cdot 3\end{array}$ & $\begin{array}{r}160 \\
125 \\
66 \\
180 \\
187 \\
601\end{array}$ & $\begin{array}{l}26 \cdot 6^{*} \\
20 \cdot 8 \\
11 \cdot 0+ \\
30 \cdot 0 \\
31 \cdot 1\end{array}$ & $\begin{array}{r}72 \\
99 \\
79 \\
120 \\
173 \\
479\end{array}$ & $\begin{array}{l}15 \cdot 0 \\
20 \cdot 7 \\
16 \cdot 5 \\
25 \cdot 1 \\
36 \cdot 1\end{array}$ \\
\hline
\end{tabular}

${ }^{*} \chi_{1}^{2}=20 \cdot 6 ; P<0 \cdot 001$

$+\chi_{1}^{2}=6 \cdot 5 ; \mathrm{P}<0 \cdot 02$

\section{Single infections}

Use of oral contraceptives in women with single infections is shown in table II. The number of oral contraceptive users in women infected with $C$ trachomatis alone was significantly increased compared with those infected with each of the other three pathogens alone and with those uninfected with any of these organisms $(P<0.002)$. The incidence of infection with $C$ trachomatis alone was $10 \cdot 8 \%$ of all oral contraceptive users in the study population compared with $5 \cdot 2 \%$ of all non-users $\left(\chi^{2}=10 \cdot 2\right.$; $\mathrm{P}<0 \cdot 002)$.
TABLE II Use of oral contraceptive agents in women with single infections

\begin{tabular}{|c|c|c|c|c|c|}
\hline \multirow[b]{2}{*}{ Pathogens } & \multirow{2}{*}{$\begin{array}{l}\text { Total } \\
\text { No of } \\
\text { women }\end{array}$} & \multicolumn{2}{|c|}{ Users* } & \multicolumn{2}{|c|}{ Statistical difference $\dagger$} \\
\hline & & No & $\%$ & $\chi^{2}$ test & Probability \\
\hline $\begin{array}{l}C \text { trachomatis alone } \\
T \text { vaginalis alone } \\
N \text { gonorrhoeae alone } \\
\text { Candida species alone } \\
\text { No pathogen isolated }\end{array}$ & $\begin{array}{r}90 \\
43 \\
68 \\
113 \\
360\end{array}$ & $\begin{array}{r}65 \\
16 \\
36 \\
64 \\
187\end{array}$ & $\begin{array}{l}72 \cdot 2 \\
37 \cdot 2 \\
52 \cdot 9 \\
56 \cdot 6 \\
51 \cdot 9\end{array}$ & $\begin{array}{r}13 \cdot 5 \\
5 \cdot 4 \\
4 \cdot 6 \\
11 \cdot 2\end{array}$ & $\begin{array}{l}<0.001 \\
<0.05 \\
<0.05 \\
<0.002\end{array}$ \\
\hline
\end{tabular}

* Of oral contraceptive agents

tIn use of oral contraceptives compared with isolation of $\vec{\odot}$ C trachomatis alone

\section{Concomitant infections}

The incidences of concomitant infection with $C$ trachomatis in all women infected with $N$ gonorrhoeae, $T$ vaginalis, and Candida species were $37 \cdot 5 \%, 29 \cdot 0 \%$, and $16 \cdot 0 \%$ respectively (table III). In each of these groups, the incidence of concomitant infection with $C$ trachomatis was significantly increased in oral contraceptive users compared with non-users.

Thus, whether occurring as the sole pathogen or in association with another genital pathogen, infection with $C$ trachomatis was significantly more common in oral contraceptive users than in non-users.

TABLE III Isolation rates of Chlamydia trachomatis in women with mixed infections

\begin{tabular}{|c|c|c|c|c|c|c|c|}
\hline \multirow[b]{3}{*}{ Pathogens } & \multirow{3}{*}{$\begin{array}{l}\text { Total No } \\
\text { of women }\end{array}$} & \multicolumn{6}{|c|}{$\begin{array}{l}\text { With concomitant chlamydial } \\
\text { infection }\end{array}$} \\
\hline & & \multicolumn{2}{|l|}{ All } & \multicolumn{2}{|c|}{ Users* } & \multicolumn{2}{|c|}{ Non-users } \\
\hline & & $\overline{N o}$ & $\%$ & $\overline{N o}$ & $\%+$ & $\overline{N o}$ & $\%+$ \\
\hline $\begin{array}{l}N \text { gonorrhoeae } \\
T \text { vaginalis } \\
\text { Candida } \text { species }\end{array}$ & $\begin{array}{l}224 \\
145 \\
300\end{array}$ & $\begin{array}{l}84 \\
42 \\
48\end{array}$ & $\begin{array}{l}37 \cdot 5 \\
29 \cdot 0 \\
16 \cdot 0\end{array}$ & $\begin{array}{l}59 \\
28 \\
38\end{array}$ & $\begin{array}{l}47 \cdot 2 \ddagger \\
42 \cdot 48 \\
21 \cdot 11\end{array}$ & $\begin{array}{l}25 \\
14 \\
10\end{array}$ & $\begin{array}{r}25 \cdot 3 \\
17 \cdot 7 \\
8 \cdot 3\end{array}$ \\
\hline
\end{tabular}

* Of oral contraceptive agent

+Based on numbers of users and non-users of oral contraceptives with each condition given in table I

$\neq \chi_{i}^{2}=10.4 ; \mathrm{P}<0.01$

$\S \chi_{1}^{2}=9.5 ; P<0.01$

$\mathbf{I} \chi_{1}^{2}=7.8 ; \mathrm{P}<0.01$

\section{DEMOGRAPHIC DATA}

Demographic and social data on all women infected $N$ with $C$ trachomatis are shown in table IV, together with a comparison of results in oral contraceptive

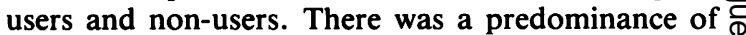
young, single, nulliparous, Caucasian women. One $\stackrel{\infty}{\rightarrow}$ hundred and fifty-seven $(63.4 \%)$ of all the 232 infected women presented to the clinic for reasons 0 other than being known contacts of men with $\stackrel{D}{\circ}$ nongonococcal urethritis. There was no difference $\mathbb{D}$ between oral contraceptive users and non-users in 
TABLE IV Demographic data on women with chlamydial infection

\begin{tabular}{|c|c|c|c|}
\hline Data & $A l l$ & Users* & Non-users* \\
\hline No of patients & 232 & 160 & 72 \\
\hline \multicolumn{4}{|l|}{ Age } \\
\hline$\%$ less than 25 years & $72 \cdot 8$ & $74 \cdot 4$ & $69 \cdot 9$ \\
\hline \multicolumn{4}{|l|}{ Marital state } \\
\hline$\%$ Single & $69 \cdot 4$ & $71 \cdot 9$ & $63 \cdot 9$ \\
\hline$\%$ Married & $10 \cdot 8$ & $7 \cdot 5+$ & $18 \cdot 1$ \\
\hline \% Divorced/separated & $19 \cdot 8$ & $20 \cdot 6$ & $18 \cdot 1$ \\
\hline \multicolumn{4}{|l|}{ Ethnic group } \\
\hline$\%$ Caucasian & $90 \cdot 5$ & $91 \cdot 3$ & $88 \cdot 9$ \\
\hline \multicolumn{4}{|l|}{ Job status } \\
\hline$\%$ Employed & $54 \cdot 3$ & $60 \cdot 6 \neq$ & $40 \cdot 3$ \\
\hline$\%$ Student & $15 \cdot 1$ & $16 \cdot 3$ & $12 \cdot 5$ \\
\hline \multicolumn{4}{|l|}{ Reason for attendance } \\
\hline$\%$ Known contacts of NSU & $36 \cdot 6$ & $36 \cdot 3$ & $37 \cdot 5$ \\
\hline$\%$ Known contacts of gonorrhoea & $34 \cdot 5$ & $34 \cdot 3$ & $\begin{array}{l}34 \cdot 7 \\
27 \cdot 8\end{array}$ \\
\hline \multirow{2}{*}{\multicolumn{4}{|c|}{ No of sexual partners in previous }} \\
\hline & & & \\
\hline$\% 0$ & $0 \cdot 4$ & & $1 \cdot 4$ \\
\hline$\% 1$ & $68 \cdot 5$ & $70 \cdot 0$ & $65 \cdot 3$ \\
\hline$\% 2$ & $23 \cdot 3$ & $25 \cdot 0$ & $19 \cdot 4$ \\
\hline$\% 3$ or more & $7 \cdot 8$ & $5 \cdot 0 \AA$ & $13 \cdot 9$ \\
\hline \multicolumn{4}{|l|}{ No of pregnancies } \\
\hline$\% 0$ & $59 \cdot 8$ & $66 \cdot 3$ & $45 \cdot 8$ \\
\hline$\% 1$ & $20 \cdot 7$ & $20 \cdot 0$ & $22 \cdot 2$ \\
\hline$\% 2$ or more & $19 \cdot 4$ & $13 \cdot 89$ & $31 \cdot 9$ \\
\hline
\end{tabular}

* Of oral contraceptive agents

$+\chi_{i}^{2}=4 \cdot 7 ; \mathrm{P}<0.05$

$\neq \chi_{1}^{2}=7 \cdot 5 ; \mathrm{P}<0 \cdot 01$

$\S \chi_{i}^{2}=4 \cdot 3 ; P<0.05$

$\mathbf{T}_{1}^{2}=9 \cdot 4 ; \mathrm{P}<0 \cdot 01$

age, ethnic group, or reason for attendance. Nonusers infected with $C$ trachomatis differed from their counterparts using oral contraceptives; more were likely to be married $(P<0.05)$, to be unemployed $(\mathrm{P}<0 \cdot 01)$, to admit to three or more sexual partners in the preceding three months $(P<0.05)$, and to have had multiple pregnancies $(P<0 \cdot 01)$. No significant differences were shown in the proportions in each group admitting to multiple sexual partners in the three months before attendance at the clinic between oral contraceptive users and non-users in the groups of women with gonorrhoea alone, trichomoniasis alone, candidosis alone, or with no infection.

\section{CONCOMITANT INFECTIONS}

In women with chlarnydial and concomitant infections there were no significant differences between oral contraceptive users and non-users in the incidence of gonorrhoea, trichomoniasis, candidosis, or infection with other STDs (table V).

\section{CLINICAL FEATURES}

The clinical details of women infected with $C$ trachomatis alone are shown in table VI. Of the 90
TABLE $\mathrm{v}$ Concomitant infections in women infected with $C$ trachomatis

\begin{tabular}{lccl}
\hline Pathogens & All & Users* & Non-users \\
\hline No of patients & 232 & 160 & 72 \\
\% With no other infection & $38 \cdot 8$ & $40 \cdot 6$ & $34 \cdot 7$ \\
\% With N gonorrhoeae & $36 \cdot 2$ & 36.9 & $34 \cdot 7$ \\
\% With T vaginalis & $18 \cdot 1$ & 17.5 & $19 \cdot 4$ \\
\% With Candida species & $20 \cdot 7$ & $23 \cdot 8$ & 13.9 \\
\% With other STD & $10 \cdot 3$ & $9 \cdot 4$ & 12.5 \\
\hline
\end{tabular}

*Of oral contraceptive agents

TABLE VI Clinical features in women infected with $C$ trachomatis alone

\begin{tabular}{|c|c|c|c|}
\hline & Total No & Users \%* & Non-users \%* \\
\hline \multicolumn{4}{|l|}{ Symptoms } \\
\hline None & 60 & $67 \cdot 6$ & $64 \cdot 0$ \\
\hline Excessive vaginal discharge & 27 & $29 \cdot 2$ & $32 \cdot 0$ \\
\hline Frequency/dysuria & 5 & $6 \cdot 2$ & $4 \cdot 0$ \\
\hline Abdominal pain & 4 & $4 \cdot \overline{6}$ & $4 \cdot 0$ \\
\hline \multicolumn{4}{|l|}{ Signs } \\
\hline No clinical abnormality & 23 & $16 \cdot 9+$ & $48 \cdot 0$ \\
\hline Cervicitis & 66 & $81 \cdot 5 \neq$ & $52 \cdot 0$ \\
\hline Vaginitis & 13 & $15 \cdot 4$ & $12 \cdot 0$ \\
\hline $\begin{array}{l}\text { No of women infected } \\
\text { with } C \text { trachomatis alone }\end{array}$ & 90 & 65 & 25 \\
\hline
\end{tabular}

women $60(66 \cdot 7 \%)$ were asymptomatic; there were no differences in the presence and type of symptoms between oral contraceptive users and non-users. However, oral contraceptive users infected with $C$ trachomatis alone had cervicitis significantly more often than non-users $(\mathrm{P}<0 \cdot 01)$.

\section{Discussion}

The isolation of $C$ trachomatis from $21 \%$ of women aged between 16 and 34 years attending the Leeds clinic is comparable with the isolation rates found in a smaller previous study ${ }^{10}$ in the same department and in recent studies elsewhere in England. ${ }^{2681314} \mathrm{It}$ is noteworthy that only $75(37 \%)$ of all 232 infections with $C$ trachomatis occurred in women who were known contacts of men with nongonococcal urethritis and who would therefore routinely have received antichlamydial therapy. This finding supports the view of those who consider that a service for culture of $C$ trachomatis is essential ${ }^{15}$ and as important as that for culture of $N$ gonorrhoeae in women attending STD clinics. We have found that infected women are usually asymptomatic and that there are no reliable clinical indicators of infection. Seventy-three per cent of women infected with $C$ trachomatis alone had some degree of cervicitis, 
although this was usually minor. The most frequent clinical abnormality was cervical mucopus associated with contact bleeding from the endocervical canal. We also noted that a small percentage of women in whom no pathogen other than $C$ trachomatis could be isolated also had a vulvovaginitis with a frothy mucopurulent vaginal discharge with or without cervical abnormalities.

The finding of a reduced incidence of trichomoniasis in oral contraceptive users in this study, in which the diagnosis was made by both microscopy and culture, confirms an earlier report, in which the diagnosis was made by microscopy alone. ${ }^{16}$ The present study suggests a clear association between $C$ trachomatis infection, whether occurring alone or with concomitant gonorrhoea, trichomoniasis, or candidosis, and the use of oral contraceptive agents. It confirms previous studies of both selected ${ }^{3}$ and non-selected ${ }^{2}$ groups of women attending STD clinics and a gynaecological clinic, ${ }^{4}$ which showed a similar increased incidence of chlamydial infection in oral contraceptive users. We found no evidence that this effect was related to increased promiscuity in such women. Indeed non-users of oral contraceptives with chlamydial infection had multiple sexual partners significantly more often. It is still not clear, however, whether the increased isolation rate is due to a greater infectivity in oral contraceptive users-perhaps because of increased exposed susceptible columnar epithelium-or to easier detection of $C$ trachomatis by present cultural methods, possibly as a result of a stimulative effect of steroids on the growth of $C$ trachomatis ${ }^{17}$ within the cervical epithelium.

This study clearly emphasises the importance of a routine chlamydial culture service in women attending STD clinics, particularly as the number of young women using oral contraceptive agents is increasing and may well serve to increase the potential reservoir for chlamydial infection within the community.
We are grateful for the technical help and expertise $\mathbb{\Phi}$ of Dr M F Hambling and Mr J J O'Neill in the isolation of $C$ trachomatis and to Mrs C Treweek and Mrs E Welch for secretarial assistance.

\section{References}

1. Paavonen J. Chlamydial infections. Microbiological, clinical and diagnostic aspects. Med Biol 1979;57:135-51.

2. Tait IA, Rees E, Hobson D, Byng RE, Tweedie MCR. है Chlamydial infections of the cervix in contacts of men with non-gonococcal urethritis. Br J Vener Dis 1980; 56: 37-45.

3. Hilton AL, Richmond SJ, Milne JD, Hindley F, Clark SKR. Chlamydia A in the female genital tract. Br J Vener Dis 1974; 50: $1-10$.

4. Ripa KT, Svensson L, Mårdh P-A, Weström L. Chlamydia @ trachomatis cervicitis in gynaecological outpatients. Obstet $=$ Gynecol 1978; 52:698-702.

5. Burns DCM, Darougar S, Thin RN, Lothian L, Nichol CS. Tे Isolation of chlamydia from women attending a clinic for STD. Br J Vener Dis 1975; 51:314-8.

6. Oriel JD, Powis PA, Reeve P, Miller A, Nichol CS. $\stackrel{\infty}{V}$ Chlamydial infections of the cervix. Br J Vener Dis 1974;50: 음 11-6.

7. Oriel JD, Johnson AL, Barlow D, Thomas BJ, Nayyar K, Reeve P. Infection of the uterine cervix with Chlamydia trachomatis. J Infect Dis 1978; 137:443-51.

8. Woolfitt JMG, Watt $L$. Chlamydial infection of the urogenital $\vec{\Phi}$ tract in promiscuous and non-promiscuous women. $\mathrm{Br} J$ Vener Dis 1977; 53:93-5.

9. Ghadrian FD, Robson HG. Chlamydia trachomatis genital $\infty$ infections. Br J Vener Dis 1979;55:415-8.

10. Nayyar KC, O'Neill JJ, Hambling MF, Waugh MA. Isolation of Chlamydia trachomatis from women attending a clinic for sexually transmitted diseases. Br J Vener Dis 1976;52:396-8.

11. Waugh MA, Nayyar K. Triple tetracycline (Deteclo) in the treatment of chlamydial infection of the female genital tract. Br J Vener Dis 1977; 53:96-7.

12. O'Neill JJ, McClean BM, Hambling MF. Isolation of 8 chlamydiae in untreated and cytochalasin B treated McCoy cells. J Clin Pathol 1978; 31: 183-4.

13. Ridgway GL, Oriel JD. Inter-relationships of Chlamydia trachomatis and other genital pathogens in the female genital tract. J Clin Pathol 1977; 30:933-6.

14. Hobson D, Johnson FWA, Rees E, Tait IA. Simplified method for diagnosis of genital and ocular infections with chlamydia. Lancet 1974; ii: 555-6.

15. Willcox JR, Fish PG, Barrow J, Barlow D. The need for a chlamydia culture service. Br J Vener Dis 1979; 55:281-3.

16. Bramley M, Kinghorn GR. Do oral contraceptives inhibit trichomoniasis? Sex Transm Dis 1979;6:261-3.

17. Bushell AC, Hobson D. Effect of control on growth of $C$ trachomatis in McCoy cells. Infect Immun 1978; 21:946-53. 